\title{
Understanding the impact of reward and recognition, work life balance, on employee retention with job satisfaction as mediating variable on millennials in Indonesia
}

\author{
Aga Hutama Tirta \\ Amelia Enrika \\ Binus Business School, Jakarta, Indonesia
}

\section{Keywords}

Employee retention, job satisfaction, millennial, reward and recognition, structural equation model, partial least square, work life balance.

\begin{abstract}
In the current condition, Millennials have the biggest portion in the workforce composition. In the next ten or fifteen years, they will be in the top management level, replacing the current management. By retaining them in the organisation, such training and recruitment cost could be minimized and bring less efforts to the organisation in recruiting new talents. This research is aimed to examine the impact of reward and recognition, work life balance on employee retention using the job satisfaction as mediating variable. This research is expected to be able to give insights to organisations to develop programs or policies to retain their current demography of the workforce, which consist of Millennials. The samples were collected by nonprobability sampling method. The statistical method used was structural equation model using partial least square software, with hypothesis testing using $t$-test and $p$ value result. For validity and reliability, average variance extracted (AVE) and composite reliability (CR) were used to determine whether the tool that was used is valid and reliable. Result of this research shows that reward and recognition, work life balance and job satisfaction have significant positive effect on the employee retention.
\end{abstract}

Corresponding author: Amelia Enrika

Email addresses for the corresponding author: ameliaenrika@gmail.com

First submission received: $20^{\text {th }}$ May 2020

Revised submission received: $7^{\text {th }}$ July 2020

Accepted: $13^{\text {th }}$ July 2020

\section{Introduction}

In the next few years, Generation $Y$ or also known as Millennial Generation, will be a demographical bonus in Indonesia, in which its population is estimated will reach $33.75 \%$ of the total of Indonesian population (Minister of Women and Children Empowerment, 2018). Explained by Jobstreet, it is estimated that Millennials will dominate 50\% of global work force population in 2020 (Hee and Rhung, 2019). In general, productive age is in the range 15-65 years old. Millennials who were born during 19812000, currently is in the productive age of 18-39 years old. They are expected to give significant and their best contribution to Indonesia's economic development. With this fortunate demographical bonus, productive Millennials become really significant to business and as the main focus in Indonesia's economy gears. 


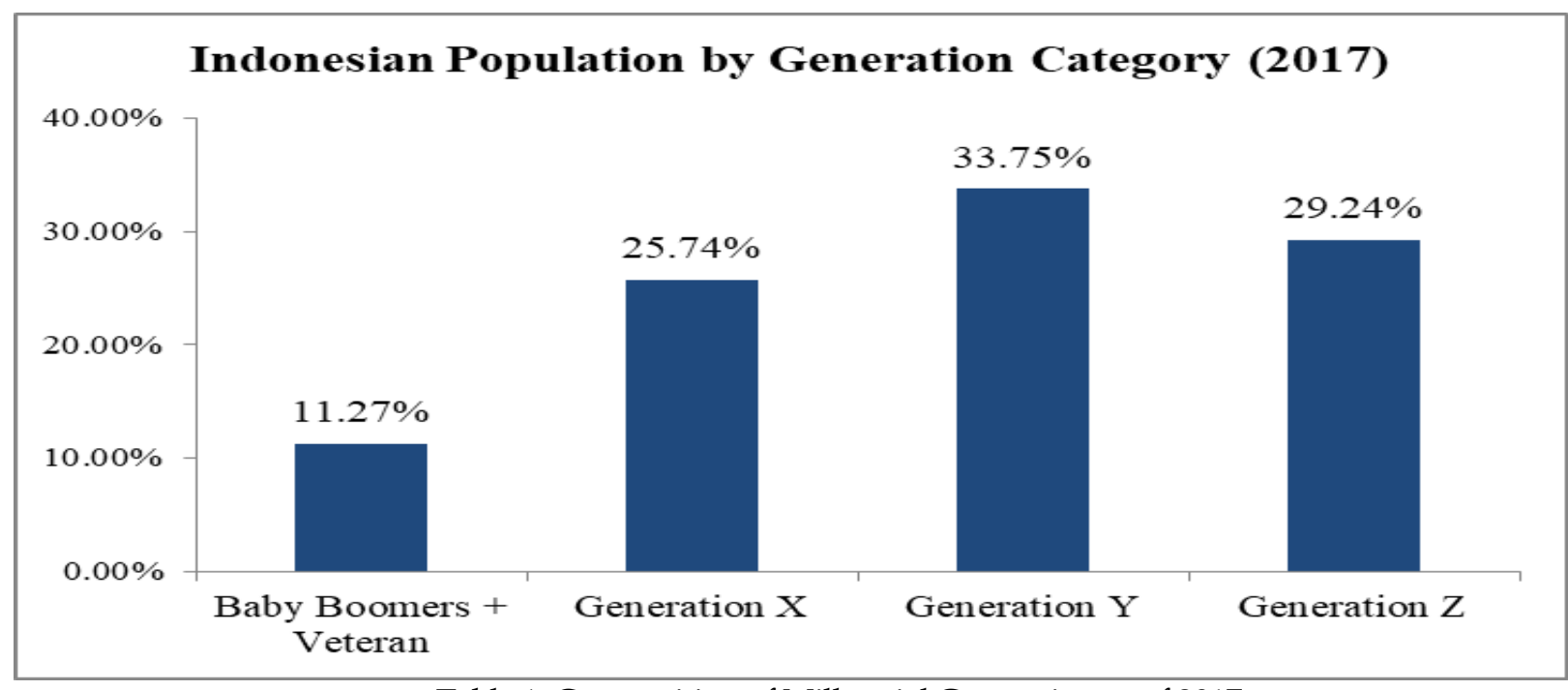

Table 1. Composition of Millennial Generation as of 2017

Source: Taken from Indonesian Survey 2017 by Minister of Women and Children Empowerment

In this current work force generation, its composition is still dominated by Generation $\mathrm{X}$ in management level and Millennials in junior level (Hee and Rhung, 2019). Gradually, however, the management level will be replaced by Millennials. Adjustments are required, considering different characteristics, behavior, and mindset between those two generations. Organisation should prepare mitigation strategy for this management shifting to Millennials and understand their characteristics in order to anticipate potential challenges. Related to their job, Millennials have different expectations compared to previous generations. These expectations arise due to strong willingness in learning, selfdevelopment, and give significant contributions to organisation or even the world. However, Millennials are prone to change their job in a short period of time due to many reasons.

The characteristics of Millennials are they tend to move unemployed to get advantages from working experiences, have priorities on job satisfaction, and also consider working environment rather than salary (Calk and Patrick, 2017). This research will focus spesifically on Millennials domiciled in Jakarta and Tangerang who are working in the companies in Jakarta and its surrounding area, due to Jakarta being the business area of Indonesia and it is expected that this research could provide insights to employers located in the areas to retain their employees that is currently dominated by Millennials.

\section{Research Problem and Objectives}

\subsection{Research Problem}

Previous research which was conducted in several countries showed positive relationship between employee retention and reward recognition and work-life balance. Research conducted by Nasir and Mahmood (2018) focused on how supervisor's support, reward and recognition and work-life policies affect employee retention. Many researches saying the major factors that affect Millennials to stay in their jobs are recognition and relationships with their co-workers.

Research that emphasize on relationships between factors such as work-life balance, compensation or rewards and recognition with employee retention are available. For an organisation, employee retention is one of the challenges that needs to be faced, especially for people in the human resource department (Too and Kwasira, 2017). Millennials are perceived to have high expectations on their work and on the organisation, they work for and they also have specific considerations on accepting work that is offered to them (Arora and Kshatriya, 2017). By having so many factors to be considered, Millennials easily change their job, move from one organisation to another. Hence, employee retention for this generation is a particular challenge faced by an organisation. 


\subsection{Research Objectives \\ Objectives of this research are:}

1. To understand whether Millennials consider reward and recognition and work-life balance as significant factors to stay in an organisation.

2. To examine whether Millennials consider reward and recognition and work-life balance as significant factors to their job satisfaction.

3. To investigate whether job satisfaction plays a significant role in mediating reward and recognition and work-life balance with employee retention to Millennials.

\subsection{Scope of Research}

This research only focused on variables that will be tested, i.e. reward and recognition, work-life balance, job satisfaction and employee retention. This research was conducted in a specific period of time when the questionnaires were distributed by researchers. Additional variables might have to be added to have complete view on factors that affect employee retention.

\section{Literature Review}

\subsection{Employee Retention}

From definition, employee retention is an effort or way to encourage employees to remain in the organisation for a long period of time. By retaining the employees within the organisation, the company is more likely to achieve its long-term goals, which is its growth. Zin et al (2012) explained that employee retention becomes an important part in a company's operational activities, especially long-term activities, i.e. to grow and take over a certain market.

Kossivi, Xu and Kalgora (2016) mentioned in their research that employee is one of the important assets of a company. Hence, employee retention is not only limited on how to attract the best talents but also to keep these talents to remain in the company in the long run. Other than the above definitions, according to Putra and Rahyuda (2016), employee retention is one of the ways that is used by top management on its employees to stay within the company in certain period of time, so that the company will gain positive impacts. Much research had been done to review employee retention strategy which could be used by employers or organisations in determining the steps to be taken to retain their employees (Raj and Brinda, 2017). Employee retention becomes important to an organisation as it is the one who keeps the company runs a sustainability in its business. Employees are considered as an asset which gives contributions to organisation in order for it to gain financial advantages and sustainable organisational development (Singh, 2019). However, the process to manage and develop human is considered a complex process. This process involves on the ways of a company could increase employee's motivation. Employees who have high motivation will impact on their performance and their organisation. Employee retention could be done by creating working environment that supports employees' motivation development. Factors such as compensation, career development, work flexibility are some examples that are considered to have impact on employee retention.

\subsection{Reward and Recognition}

Ndungu (2017) explained that reward and recognition as an effort by organisation or company's management to appreciate employees or its member as a response for being a role model or for their certain actions. Reward is also expected to boost employees' motivation as they will obtain something in return for their achievements or contributions to organisation or company. In other theories, reward is categorized into implicit and explicit reward. Explicit reward is given in form of salary and incentives while implicit rewards are given in a manner of appreciation, recognition (e.g. best employee), and compliments. Rewards that are given should be based on fair and objective evaluation. Brun and Dugas (2008) explained that employee recognition is a common problem faced by most organisations, as recognition is one of the basic needs of an individual. In an organisation, recognition could be elaborated in certain policies or efforts, claiming that organisation wants to recognize results or efforts from its employees. Dimensions of recognition are created based on formed relationships as follows: 
- Relationships with organisation: company's intention to acknowledge and listen to employees.

- Vertical relationships: relationship between employees and leaders.

- Horizontal relationships: relationship between employees and co-workers.

- External relationships: relationships with external parties, including with consultants and business partners.

- Social relationships: relationship between company and employee with certain community.

Tessema et al (2013) in their research in Vietnam, United States, and Malaysia explained that giving recognition to members/employees creates more motivation compared to giving monetary benefits (salary, money, or other benefit packages). To conclude, recognition plays a significant role in an organisation to retain its talents.

By connecting the above variables (reward and recognition) with characteristics of current workforce generation, which is dominated by Millennials that will be the top management, research by Close and Martin (2015), showed that Baby Boomers, Generation X, and Millennials consider that reward and recognition are one of the significant factors in employee retention process. The following table is the research results in the previous 5 years that evaluate on relationships between reward and recognition with job satisfaction and employee retention:

\begin{tabular}{|c|c|c|}
\hline Researchers & Year & Results \\
\hline $\begin{array}{l}\text { Ahmad, Ali, } \\
\text { Nisar and } \\
\text { Ahmed }\end{array}$ & 2017 & $\begin{array}{l}\text { In this research, the subjects were lecturers in all universities in Gujranwala, } \\
\text { Pakistan. Based on the result, reward and recognition positively have impact and } \\
\text { show important role on job satisfaction and are expected to be able to increase } \\
\text { organisation's capabilities in global business competition. }\end{array}$ \\
\hline $\begin{array}{l}\text { Baskar and } \\
\text { Rajkumar }\end{array}$ & 2015 & $\begin{array}{l}\text { In this research, the subjects were employees of Aloft Hotel, India. Based on the } \\
\text { research result, there is direct positive relationship between reward and recognition } \\
\text { and job satisfaction. It is also concluded that the better the reward and recognition, } \\
\text { the higher the motivation and employee's job satisfaction are in an organisation. On } \\
\text { the other hand, the research subjects also emphasized the importance of monetary } \\
\text { reward and the organisation was expected to consider financial incentive in order to } \\
\text { increase the employee's job satisfaction level. }\end{array}$ \\
\hline $\begin{array}{l}\text { Oyoo, } \\
\text { Mwandihi, } \\
\text { Musiega and } \\
\text { Douglas }\end{array}$ & 2016 & $\begin{array}{l}\text { Research subject were employees in a hospital in Mukumu, Kenya. Based on the } \\
\text { research result, reward, and recognition (implicit and explicit) positively gave impact } \\
\text { and played significant role on employee retention. It is suggested that benefits and } \\
\text { package for employees should be made clear. Organisation is also suggested to have } \\
\text { policies and standard on the intrinsic reward. Employee package is also suggested to } \\
\text { be realistic and reliable. }\end{array}$ \\
\hline
\end{tabular}

Table 2. Previous Research on the Impact of Reward and Recognition to Job Satisfaction and Employee Retention

Source: modified by author

From the above table, the research model and hypothesis are as follows:

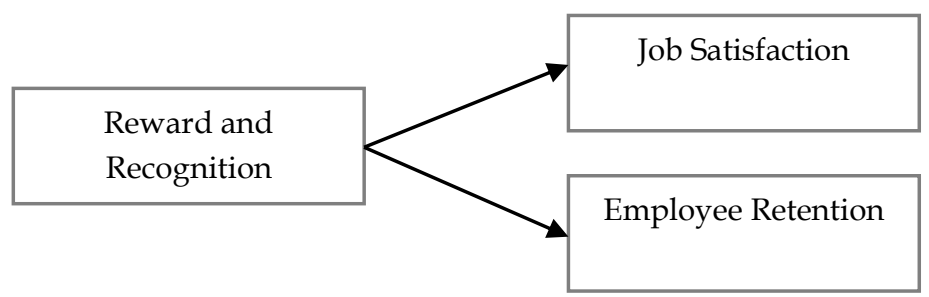

Figure 1. Relationship Model of Reward and Recognition, Work-life Balance, Employee Retention and Job Satisfaction

H1: There is significant positive effect between reward and recognition with job satisfaction

H3: There is significant positive effect between reward and recognition with employee retention 


\subsection{Work-life Balance}

Agha et al (2017) explained that work-life balance is a process to find the right balance between work and personal life, and comfortable feelings on work commitment and family. The research result explained that work which is intervened by personal life or vice versa has negative relationship with job satisfaction. In Millennials' context, work-life balance is one of the life aspects that becomes a priority to this generation (Kumar and Velmurugan, 2018). Based on Kalliath and Brough (2008), balance attainment between personal life and work has been a specific attention by organisation and employees. It is also supported by much research on work-life balance.

Millennial's life is generally exposed to their parent's life events that have high divorce rate and employment termination. Due to these circumstances, Millennials are prone to focus on family than their career, so there is an orientation shift compared to the previous generations. Millennials would rather have flexibilities in their workplace than working environment that has extensive regulations (Kaifi et al, 2012). Much research had been done to show the importance of work-life balance for Millennials. Buzza (2017) explained that Millennials perceives money as an important thing, but not more than work-life balance at work. In an organisation, a balanced condition between work and personal life itself will result in a good productivity for the employees and organisation itself (Garg and Yajuverdi, 2016). Kumar and Velmurugan (2018) explained that work-life balance could be facilitated by organisation through flexible working schedule, telecommuting facility, and family-friendly working environment. Employees who find that they are being facilitated properly will tend to stay in the organisation. Company image will also be formed as a company that supports its employee's welfare and attracts the future workforce as a preferable company to work for. The following table is the previous 5 years research on work-life balance with employee retention:

\begin{tabular}{|c|c|c|}
\hline Researchers & Year & Results \\
\hline $\begin{array}{l}\text { Nasir and } \\
\text { Mahmood }\end{array}$ & 2016 & $\begin{array}{l}\text { The research subjects were employees in Pakistan with various profession } \\
\text { backgrounds. The result was work-life balance has a positive relationship with } \\
\text { employee retention. However, the research also acknowledges that not all the needs } \\
\text { could be fulfilled by organisation. Priority scale should be made on those needs. }\end{array}$ \\
\hline $\begin{array}{l}\text { Garg and } \\
\text { Yajurvedi }\end{array}$ & 2016 & $\begin{array}{l}\text { The subject research was employees in an IT company in Noida, India. Based on the } \\
\text { research, work-life balance has positive impact on employee retention. Success in } \\
\text { implementing work-life balance within an organisation is believed to increase job } \\
\text { satisfaction level, employee performance and increase best talent retention while on } \\
\text { the same time, decrease absences. This research supports organisation to take roles } \\
\text { actively to make policies related work-life balance. }\end{array}$ \\
\hline $\begin{array}{l}\text { Mas-Machuca, } \\
\text { Berbegal- } \\
\text { Mirabent, and } \\
\text { Alegre }\end{array}$ & 2016 & $\begin{array}{l}\text { Research was conducted on employees in pharmaceutical companies in Spain to } \\
\text { discover the relationship between job autonomy as well as supervisor's support for } \\
\text { employee work-life balance and employee's job satisfaction. This research also used } \\
\text { organisational pride as mediating variable between employee work life balance and } \\
\text { job satisfaction. The result showed that job autonomy makes the work be more } \\
\text { flexible which increases the work-life balance. }\end{array}$ \\
\hline
\end{tabular}

Table 3. Previous Research on the Impact of Work Life Balance to Job Satisfaction and Employee Retention

Source: modified by author 
From the above table, the research model and hypothesis are as follows:

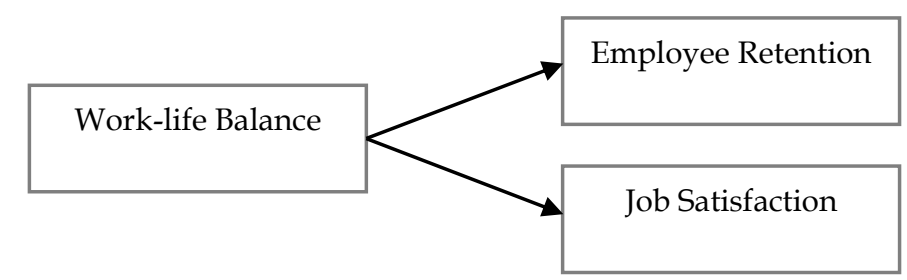

Figure 2. Relationship Model on Work-life Balance, Employee Retention and Job Satisfaction

H4: There is significant positive effect between work-life balances with employee retention

H5: There is significant positive effect between work-life balances with job satisfaction

\subsection{Job Satisfaction}

Based on the research conducted by Imran et al (2014), job satisfaction is the feeling or opinion of somebody within the organisation or company on his/her job. Thiagaraj and Thangaswamy (2017) defined job satisfaction as a pleasuring emotional condition resulted from the evaluation on the job done by someone and their achievements. The degree of job satisfaction comes from related factors, i.e. personal factors (age, education, and working experiences), job factor (type of work, required skills, responsibility and job status), and also factors that are affected by the management such as salary, working environment, benefits, security and promotion opportunities.

Employees' satisfaction on their job is one of the important aspects in an organisation. Employees who have high degree of job satisfaction tend to be more loyal to the organisation and stay within the organisation during the difficult times. In its relation to employee retention, Inda (2016) explained that job satisfaction has significant impact on employee retention in an organisation, even though with the intervention from facilitating working environment and proper and good salary, or other variables. Similar research was conducted by Javed and Balouch (2014), when employee's job satisfaction is at its lowest point; employee will leave the organisation intentionally.

In a bigger scale, job satisfaction does not only have impact on employee retention, but other aspects such as employee productivity and organisation performance (financial and non-financial). With high degree of job satisfaction, it is expected that organisations would compete with their competitors to retain their best talents in order to minimize investment on human resource to replace departing senior employees (e.g. recruitment cost, training cost or third-party recruitment fee). The following table summarizes the previous 5 years research on relationship between job satisfaction and employee retention:

\begin{tabular}{lll}
\hline Researchers & Year & Results \\
\hline $\begin{array}{l}\text { Nasir and } \\
\text { Mahmood }\end{array}$ & 2016 & $\begin{array}{l}\text { The research subjects were employees in Pakistan with various profession } \\
\text { backgrounds. The result was job satisfaction has a positive relationship with } \\
\text { employee retention. However, the research also acknowledges that not all the needs } \\
\text { could be fulfilled by organisation. Priority scale should be made on those needs. }\end{array}$ \\
\hline $\begin{array}{l}\text { Khan and } \\
\text { Aleem }\end{array}$ & $\begin{array}{l}\text { Subject on this research is the employees from Medical Institution of Health } \\
\text { Department in Punjab Province, India. The research result explained that variables } \\
\text { such as salary, promotion, working environment and job characteristics are } \\
\text { perceived to be important to job satisfaction in the department. The researchers also } \\
\text { suggested the management of the company to consider those variables to avoid the } \\
\text { high employee turnover. }\end{array}$ \\
\hline
\end{tabular}

Table 4. Previous Research on the Impact of Job Satisfaction and Employee Retention

Source: modified by author 
From the above table, the research model and hypothesis is as follow:

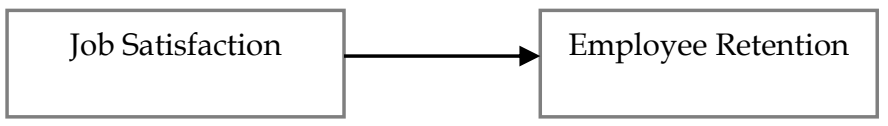

Figure 3. Relationship Model on Job Satisfaction and Employee Retention

H2: There is significant positive effect between job satisfactions with employee retention

\subsection{Theoretical Framework}

Based on the elaboration in Literature Review, the developed theoretical framework is as follows:

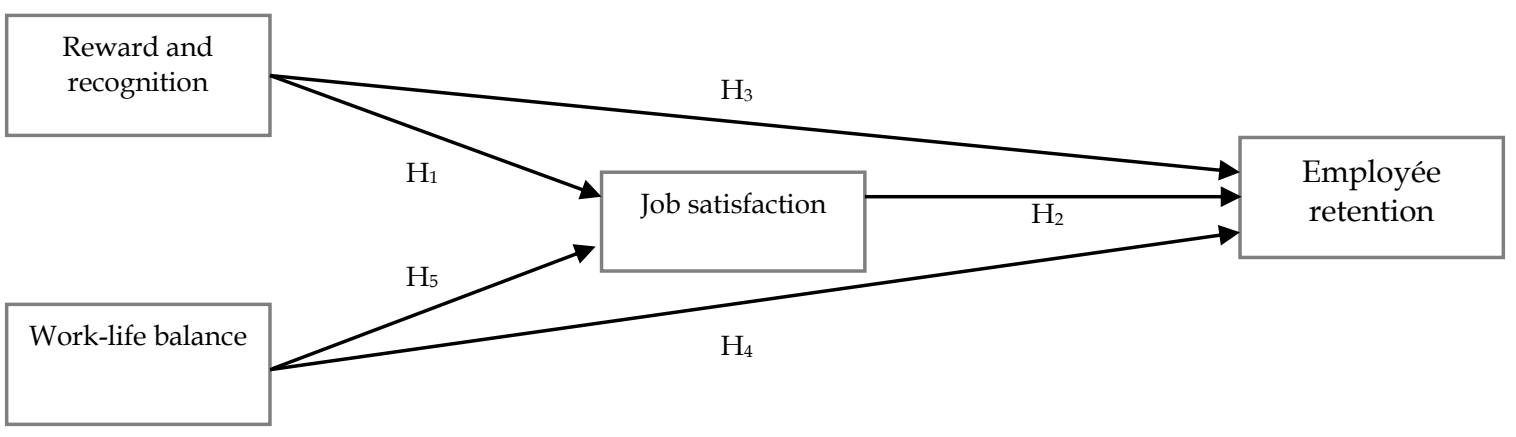

Figure 4. Proposed research model

The above theoretical framework was developed based on consideration that reward and recognition and also work-life balance are the main factors that presumed to be important to Millennials, for them to stay within an organisation. However, we perceive that these two variables may affect employee retention directly or indirectly (mediated) by other aspects. Job satisfaction is also considered to have important role to achieve employee retention, in regard to the aforementioned of the two variables.

\section{Research Method}

\subsection{Measurement}

This research was conducted with quantitative methodology, where numerical data is used and analysed with certain statistical technique to answer questions or statements. Quantitative research methodology was chosen because this method could reveal the cause and effect, test the hypothesis, and create prediction in a research. It is considered to align with the research objective which will be conducted, testing hypothesis on reward and recognition, job satisfaction, work-life balance, and employee retention. On the other hand, quantitative method also has its own advantage, where scientific data analysis could be used to generalize conclusions. Questionnaire was designed in three parts. Respondents were asked with the screening question in the first part to determine if they are in the Millennial Generation bucket. Second part is for the questions related to the demography; gender, age, and educational background. Last part is focused on the statements in Likert scale to measure identified variables.

\subsection{Data Collection and Analysis}

Millennial generations are people who were born during 1981 to 2000. The targeted population is Millennials who reside in Jakarta and Tangerang. This research used non-probability sampling and data were collected through online survey in Google form. Considering this research will use Partial Least Square-Structural Equation Modeling (PLS-SEM), which excel in small number of samples, we collected 50 respondents and all of the questionnaires were returned. After all the data were collected, analysis was performed in PLS-SEM. PLS-SEM is commonly used in marketing and management research to analyse 
causal relationship (Hair, Ringle and Sarstedt, 2011). SEM comprises two approaches: covariance-based SEM and partial least square. This research adopted PLS-SEM for hypothesis testing and measurement validation. In addition, SEM permits several relationships to be tested at once in a single model with various relationships instead of examining each relationship individually. It also has the ability to create accessible parameter estimates for the relationships between unobserved variables (Hussain et al, 2018).

According to Hair et al (2018), research should use PLS-SEM when:

- the analysis is concerned with testing a theoretical framework from a prediction perspective.

- the structural model is complex and includes many constructs, indicators and or model relationships.

- the research objective is to better understand increasing complexity by exploring theoretical extensions of established theories (exploratory research for theory development).

- the path model includes one or more formatively measured constructs.

- the research consists of financial ratios or similar types of data artifacts.

- the research is based on secondary/archival data, which may lack a comprehensive substantiation on the grounds of measurement theory.

- a small population restricts the sample size (e.g. business-to-business research); but PLS-SEM also works very well with large sample sizes.

- distribution issues are a concern, such as lack of normality; and

- research requires latent variable scores for follow-up analyses.

\section{Results and discussion}

5.1 Results

Demography of the respondents were shown below in Table 5, in which the gender was dominated by male $(56 \%)$, the age category was dominated by respondents with age range of $26-30$ years old $(60 \%)$ while the education background was dominated by bachelor degree graduates (92\%).

\begin{tabular}{lcc}
\hline Description & $\begin{array}{c}\text { Total } \\
\text { Respondents }\end{array}$ & $\%$ \\
\hline Gender & & \\
\hline Male & 28 & $56 \%$ \\
Female & 22 & $44 \%$ \\
\hline Age category & & $6 \%$ \\
\hline 20-25 years old & 3 & $60 \%$ \\
26-30 years old & 30 & $34 \%$ \\
30-39 years old & 17 & $92 \%$ \\
\hline Education background & & $8 \%$ \\
\hline Bachelor's degree & 46 & \\
Master's degree & 4 & \\
\hline
\end{tabular}

Table 5. Demographic Characteristics of Respondents

Source: modified from the respondent's questionnaire

Measurement model is to determine whether the tool that is used are valid and reliable to achieve the objectives of the research. Structural model is to determine whether the hypothesis can be accepted or rejected according to such benchmark (T-stat and p-value). The significance level was set at $5 \%$. All outer loadings are expected to be higher than the threshold amount of 0.6 (Kwong and Wong, 2013). Table 6 summarizes the value of AVE and CR. The result showed that the factor loading, AVE and CR for each variable is above the threshold mentioned above. Hence, the tools that being used in this research have met their purpose and have been consistent in order. 


\begin{tabular}{|c|c|c|c|c|c|}
\hline Variables & Items & Factor & & 1 & $C R$ \\
\hline valiavies & Items & Loading & VE & & $\mathrm{CN}_{1}$ \\
\hline \multirow{3}{*}{ Job satisfaction (JS) } & JS1 & 0.913 & \multirow{3}{*}{0.731} & \multirow{3}{*}{0.889} & \\
\hline & JS2 & 0.710 & & & \\
\hline & JS3 & 0.924 & & & \\
\hline \multirow{3}{*}{$\begin{array}{l}\text { Reward and recognition } \\
(R R)\end{array}$} & RR1 & 0.710 & \multirow{3}{*}{0.746} & \multirow{3}{*}{0.897} & \\
\hline & RR2 & 0.933 & & & \\
\hline & RR3 & 0.929 & & & \\
\hline \multirow{3}{*}{ Work life balance (WLB) } & WLB1 & 0.816 & \multirow{3}{*}{0.762} & \multirow{3}{*}{0.906} & \\
\hline & WLB2 & 0.926 & & & \\
\hline & WLB3 & 0.874 & & & \\
\hline \multirow{5}{*}{ Employee retention (ER) } & ER1 & 0.776 & \multirow{5}{*}{0.672} & \multirow{5}{*}{0.911} & \\
\hline & ER2 & 0.873 & & & \\
\hline & ER3 & 0.788 & & & \\
\hline & ER4 & 0.870 & & & \\
\hline & ER5 & 0.788 & & & \\
\hline
\end{tabular}

Table 6. Convergent Validity and Reliability

Source: PLS SEM - modified by author

Referring to Figure 2 below, noted that $\mathrm{H} 1-\mathrm{H} 4$ are supported because it showed positive value of beta and p-value with value of less than 5\%. H5 (work-life balance) has positive effect, however its pvalue is greater than $5 \%$, hence the related hypothesis is rejected. R2 shows 0.732 , indicates that reward and recognition and work-life balance can explain $73.2 \%$ the job satisfaction variable. In addition, job satisfaction contributes $84.7 \%$ to the employee retention. From the result, almost of each hypothesis is supported according to the model that has been determined earlier. Among the independent variables, the reward and recognition have the biggest effect compared to other variables with the beta value of 0.80 . The variable which has the second highest influential effect is job satisfaction with beta of 0.53 . On the other hand, work-life balance did not have a significant effect on the job satisfaction with beta of only 0.11. The further discussion will be discussed in the section 5.2.

In addition, Figure 2 describes the structural model that has been made with the statistical test results. Related hypothesis can be accepted if the coefficient values has positive amount and p-value is smaller than $5 \%$ or T-stat is higher than 1.96 (using Z-table with significance rate is $5 \%$ ). It can be concluded that H1-H4 are accepted due to the positive coefficient, T-stat is higher than 1.96 or p-value is lower than $5 \%$.

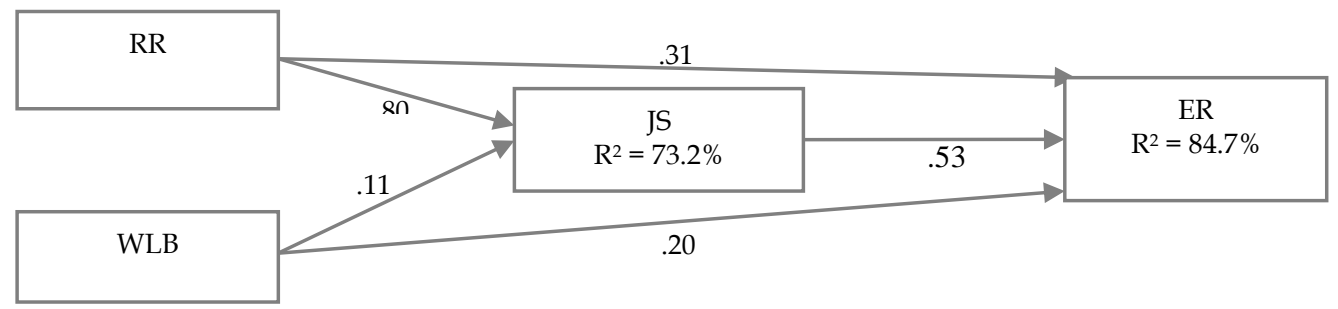

Figure 2. Structural Model

\begin{tabular}{llllll}
\hline Hypothesis & Path & a & T-stat & P-value & Decision \\
\hline H1 & RR -> JS & 0.804 & 11.718 & 0.000 & Supported \\
H3 & RR -> ER & 0.311 & 2.619 & 0.009 & Supported \\
H2 & JS -> ER & 0.531 & 4.700 & 0.000 & Supported \\
H4 & WLB -> ER & 0.204 & 3.754 & 0.000 & Supported \\
H5 & WLB -> JS & 0.113 & 1.215 & 0.225 & Not supported \\
\hline
\end{tabular}

Table 7. Hypothesis Result

Source: PLS SEM - modified by author

www.jbrmr.com A Journal of the Centre for Business \& Economic Research (CBER) 


\subsection{Discussion}

The aim of this research is to understand on what factors that can affect Millennials to stay for a longer period in their organisation. From the result of the data taken, the conclusion is that the Millennials deemed that reward and recognition, job satisfaction, and work-life balance are some factors that are to be considered in deciding to stay for a longer tenure in an organisation. This research is in line with the previous research (Nasir and Mahmood, 2016; Garg and Yajurvedi, 2016). However, the previous research did not specify Millennials as the main subject. Generally, job satisfaction has positive effect to employee retention. The specific effect resulted the tenure of the respondents has been by average 5 years working tenure in their organisation. Millennials nowadays are racing to work in the start-up company, which let them to work with flexible culture and working environment, i.e., open space area, no rule of attire, in addition to the higher pay for the sophomores.

Millennials have different work values, compared to other generations. This leads to their significant consideration on quality of life rather financial return in their work values. They may believe that there is more to life than salary (Twenge et. al., 2010). However, at the same time, they are faced with high living cost and requirement on higher level of education and its cost. Therefore, a job or employer that provides higher salary is more preferable to this generation. The research result supports this perspective. Reward and recognition have significant positive effect to job satisfaction and has indirect significant positive effect to the employee retention. This leads to the conclusion that job satisfaction is mediating the relationship between reward and recognition to the employee retention. However, on other hand, H5 was not supported in this research. The reason might be due to overtime culture that is common in the current working environment. Additional workload that needs to be done in the certain period of timeline may result in long working hour to achieve the submission target. Millennials have expectations that they can have more social life with the colleague or their family members after working hour. Hence, due to these reasons, their social time can be reduced. To understand this phenomenon, certain workforces, such as consultant firm, spend longer time in the office since they have specified deadlines that need to be met and achieved.

\section{Conclusion}

Initially, the study concluded that all of the dependent variables played the role towards the employee retention in our respondents. However, work-life balance does not support the increment of job satisfaction level. Current top-level management might need different approach to understand on expectations from Millennial workforce, as they have unique characteristics. Therefore, discussion between top-level and current workforce needs to be intensified in order to have clear understanding. Once the management has clear understanding on the expectations, management needs to determine the actions to be taken to retain their Millennials best talents.

\section{Implication and Suggestion for Future 7.1 Implication}

These results provide the necessary implication for the readers, such as business and academic purposes. For business, it is on how the policies and strategies can be taken in order to retain their Millennials employees. Some policies, such as working from home, birthday leave and paternity leave, might be considered. While these forms of rewards are not immensely popular in Indonesia, it might need to be highlighted by the employers to attract the talents. In addition, Millennials quite glorify working in start-up companies while traditional companies are not really popular as designated workplace. Thus, the recruiters and current employers may need to think on how they can attract Millennials workforce to join the organisation and stay longer, particularly with the above-mentioned aspects. For academic purposes, these further efforts need to be identified, since in this study, work life balance did not have positive effect to job satisfaction. It might be due to the characteristics of the Millennials in Jakarta and its surrounding areas that are different from the Millennials in the other areas in Indonesia. However, it should also be noted that most of Millennials emphasize on their life quality and not only valued the monetary aspects in 
their life. It should also be noted that this research needs broader samples in order to provide proper conclusion if we relate it to Indonesia's population.

\subsection{Suggestions for Future}

This study has several limitations that can be addressed in the next research. First is to add more samples of other big cities in Indonesia, e.g. Medan, Surabaya, Jogjakarta, but not limited to the cities in Java Island. Therefore, samples can be expanded as well as to explore more variables that can affect the employee retention. By having additional variables, business owners or organisations can determine on what factors need to be highlighted when they want to retain the talents.

\section{References}

Agha K., Azmi, F. T., \& Irfan, A. (2017). Work-Life Balance and Job Satisfaction: An Empirical study Focusing on Higher Education Teachers in Oman. International Journal of Social Science and Humanity, 7(3), 164-171.

Ahmad, Z., Liaqat, A., Nisar, Q. A., \& Ahmed, I. (2017). Impact of Rewards, Recognition \& Job Stress on Job Performance and Job Satisfaction. International Journal for Research in Business, Management and Accounting. 3, 1-17.

Arora, P., \& Kshatriya, Dr. K. P. (2017). Millennials: The New Generation with High Employ-ment Expectations. International Journal of Advance Research in Computer Science and Management Studies, 5(8), 101-109.

Baskar, \& Rajkumar, P. (2015). A Study on the Impact of Rewards and Recognition on Employee Motivation. International Journal of Science and Research. 4(11), 1644-1648.

Brun, J.P., \& Dugas, N. (2008). An analysis of employee recognition: Perspectives on hu-man resources practices. The International Journal of Human Resource Management. 19(4), 716-730.

Buzza, John S. (2017). Are You Living to Work or Working to Live? What Millennials Want in the Workplace. Journal of Human Resource Management and Labor Studies, 5(2), 15-20.

Close, D., \& Martins, N. (2015). Generational Motivation and Preference for Reward and recognition. Journal of Governance and Regulation. 4(3), 259-270.

Calk R., \& Patrick, A. (2017). Millennials Through the Looking Glass: Workplace Motivating Factors. The Journal of Business Inquiry, 16, 131-139.

Garg, P., \& Yajurvedi, Dr. N. (2016). Impact of Work-life Balance Practices on Employees Retention and Organisational Performance - A Study on IT Industry. Indian Journal of Ap-plied Research, 6(8), 105-108.

Hair, J. F., Ringle, C. M., and Sarstedt, M. (2011). PLS-SEM: Indeed, a silver bullet. The Journal of Marketing Theory and Practice, 19(2), 139-151.

Hair, Josep F, Risher, Jeffrey J, Sarstedt, Marko \& Ringle, Christian M. (2018). When to use and how to report the results of PLS-SEM. European Business Review, 31 (1), 2-24.

Hee, O. C., \& Rhung, L. X. (2019). Motivation and Employee Retention among Millennials in Malaysia. International Journal of Academic Research in Business and Social Sciences, 9(2), 876-884.

Hussain, Shahid, Fangwei, Shu, Siddiqi, Ahmad Faisal, Ali, Zaigham \& Shabbir, Muhammad Salman. (2018). Structural Equation Model for Evaluating Factors Affecting Quality of Social Infrastructure Projects. Sustainability 10, 1415, 1-25.

Imran, A., Ahmad, S., Nisar, Q. A. \& Ahmad, U. (2014). Exploring Relationship among Re-wards, Recognition and Employees' Job Satisfaction: A Descriptive Study on Libraries in Pakistan. Middle East Journal of Scientific Research: 21 (9): 1533-1540.

Inda, S. S., \& Mishra, Dr. S. (2016). A Study on Influence of Employee Compensation, Job Satisfaction, Working Environment on Employee Retention. International Journal of Advance Research and Innovative Ideas in Education, 2(1), 407-415.

Javed, M., \& Balouch, R. (2014). Determinants of Job Satisfaction and its Impact on Employee Performance and Turnover Intentions. International Journal of Learning \& Development, 4(2), 120-140.

Kaifi, A., Nafei, A., Wageeh, K., Nile M., \& Kaifi, M. M. (2012). A Multi-Generational Workforce: Managing and Understanding Millennials. International Journal of Business and Management, 7(24), 88-93.

Kalliath, T, \& Brough P. (2008). Work-life balance: A Review of the Meaning of the Balance Construct. Journal of Management \& Organisation, 14, 323-327.

Khan, A. H. \& Aleem, M. (2014). Impact of Job Satisfaction on Employee Turnover: An Empirical Study of Autonomous Medical Institutions of Pakistan. Journal of International Studies, 7(1), 122-132.

Kossivi, B., Xu, M., \& Kalgora, B. (2016). Study on Determining Factors of Employee Retention. Open Journal of Social Sciences, 4, 261-268. 
Kumar, K., \& Velmurugan, R. (2018). A Study on Work Life Balance of Generation Y Information Technology (IT) Employees in Cochin. International Journal of Engineering \& Technology, 7(3.6), 142-147.

Kwong, K., \& Wong, K. (2013). Partial Least Squares Structural Equation Modelling (PLS-SEM) Techniques Using SmartPLS. Marketing Bulletin, 2013, 24, Technical Note 1.

Mas-Machuca, M., Berbegal-Mirabent, J. \& Alegre, I. (2016). Work-life Balance and Its Relationship with Organisational Pride and Job Satisfaction. Journal of Managerial Psychology, 31(2), 586-602.

Minister of Women and Children Empowerment. (2019). Indonesian Millennial Generation's Profile.

Nasir, S. Z. \& Mahmood, N. (2016). Determinants of Employee Retention: An Evidence from Pakistan. International Journal of Academic Research in Business and Social Sciences. 6(9), 182-194.

Nasir, S. Z. \& Mahmood, N. (2018). A Study of Effect of Employee Retention on Organisational Competence. International Journal of Academic Research in Business and Social Sciences, 8(4), 408-415.

Ndungu, D. N. (2017). The Effects of Rewards and Recognition on Employee Performance in Public Educational Institutions: A Case of Kenyatta University, Kenya. Global Journal of Management and Business Research: An Administration and Management, 17(1), 42-68.

Oyoo, Mark Okinyi, Mwandihi, Nicholas Kadaga \& Musiega, Douglas. (2016). Influence of reward systems on employee retention in faith-based health organisations in Kenya: a case of Mukumu Hospital, Kenya. International Journal of Commerce and Management Research. 2(10), 42-51.

Putra, I. B. G. S., \& Rahyuda, A. G. (2016). Effect of Compensation, Working Environment and Perceived Organisational Support (POS) on the Employee Retention, E-Journal Management Unud, 5(2), 810-837. (Pengaruh Kompensasi, Lingkungan Kerja Dan Perceived Organisational Support (Pos) Terhadap Retensi Karyawan. E-Jurnal Manajemen Unud, 5(2), 810-837).

Raj, S. R., \& Brindha, Dr. G. (2017). A Study on Employee Retention Strategies with Special Reference to Chennai IT Industry. International Journal of Civil Engineering and Technology, 8(6), 38-44.

Singh, D. (2019). A Literature Review on Employee Retention with Focus on Recent Trends. International Journal of Scientific Research in Science and Technology, 6(1), 425-431.

Thiagaraj D \& Thangaswamy. (2017). Theoretical Concept of Job Satisfaction - A Study. International Journal of Research, 5(6), 464.

Tessema, M. T., Ready, J. K., \& Embaye, B. A. (2013). The Effects of Employee Recogni-tion, Pay, and Benefits on Job Satisfaction: Cross Country Evidence. Journal of Business and Economics, 14(1), 1-12.

Twenge, J. M., Campbell, S. M., Hoffman, B. J., \& Lance, C. E. (2010). Generational Differences in Work Values: Leisure and Extrinsic Values Increasing, Social and Intrinsic Values Decreasing. Journal of Management, 36(5), 1117-1142.

Too, R., \& Kwasira, Dr. J. (2017). Evaluation of Employee Retention Practices to Generation Y at Cooperative Bank in the County of Nairobi, Kenya. European Journal of Business and Management, 9(11), 43-53.

Zin, S. M, Ahmad, N., Ngah, N. E. B., Simail, R. B., Ibrahim, N. B., Abdullah, I. H. T. B. \& Tajudin, N. H. B. A. (2012). Motivation Model for Employee Retention: Applicability to HRM Practices in Malaysian SME Sector. Canadian Social Science, 8(5), 8-12. 